\title{
Contemplating the Islamic Garden and Malay Traditional Landscape from the Quran
}

\author{
Nur Huzeima Mohd Hussain, Khalilah Hassan, Norizan Mt Akhir \\ Faculty of Architecture, Planning \& Surveying, \\ Universiti Teknologi MARA, Seri Iskandar Campus, Seri Iskandar, 32610 Perak, Malaysia \\ nurhu154@perak.uitm.edu.my
}

\begin{abstract}
Beliefs and interpretations from the Islamic concept have influenced the emergence and extensions of many landscape designs including the Malay landscape. This paper contemplates the significant relation between the Malay landscape and Islamic garden concept through established references. The main intention is to identify, analysing and establishing the landscape elements, design characteristic and their functions as the research attributes. This paper uses the imagery evidence from the Quran to support the study analyses and discussions. The conclusions will lead towards all possible dimensions of Islamic Malay landscape in cultural, traditional and sustainability context for future resilient.
\end{abstract}

Keywords: malay; landscape; element; Islamic concept

eISSN 2398-4295 @ 2018. The Authors. Published for AMER ABRA cE-Bs by e-International Publishing House, Ltd., UK. This is an open-access article under the CC BY-NC-ND license (http://creativecommons.org/licenses/by$n c-n d / 4.0 /)$. Peer-review under responsibility of AMER (Association of Malaysian Environment-Behaviour Researchers), ABRA (Association of Behavioural Researchers on Asians) and $C E-B s$ (Centre for EnvironmentBehaviour Studies), Faculty of Architecture, Planning \& Surveying, Universiti Teknologi MARA, Malaysia.

DOI: http://dx.doi.org/10.21834/ajbes.v3i13.142 


\subsection{Introduction}

The Holy Quran has brought with its revelation over the past 14th century, many concepts relating the man and nature. One of the concepts that relate to this relationship is 'garden'. 'Garden' were mentioned 164 times in the Quran, which showed the importance of garden to man. From early living, the garden has played a major role in human civilisation a and 'Islamic Garden' was recorded to be one of the early gardens which representing the earthly image of 'Paradise' (Kamil \& Yunos, 2015). The Islamic Garden which acknowledged during the 7th century through the establishment of Persian Garden. Islamic garden has inspired and influenced the emergence and extensions of many landscape designs such as the Moorish garden, European garden, Mexican landscape and Asian landscape including the Malay landscape.

The understanding of both the Islamic garden concept and Malay landscape are vast. Particularly on the background history and culture, design inspirations, conceptual development and implementations. However, the relation and discussion between both concepts are still vague. This paper reviews the significant to the relationship between the Malays and Islamic concept through established references. The reviews also adopted relevant studies and Quran citation to support the discussions.

The main intention is to investigate, understand and document the fundamental findings in which are important for future discourse on Islamic and Malay contemporary landscape design. This study highlighted the landscape elements, plants selections and their functions as the research attributes. The exploration conducted was to identify the character, similarities and differences between both landscape designs. The concern is to establish potential attributes that would be reasonably reliable in enhancing the Islamic-Malay landscape design in future.

Furthering such discourse and exploration are central to the discussion as it involved theoretical and practical understandings of how the Islamic concept influenced the Malay landscape design. In particular, this paper will also address on the verse from Quran that can support clarifications and evidence. The conclusions will lead towards all possible dimensions of Islamic-Malay landscape in cultural, traditional and sustainability context for future undertakings.

\subsection{The Malay Traditional Landscape}

The Malay traditional landscape is tolerant to the external spaces or traditional Malay house compound. The landscape surrounding the house reflects the simplicity of the traditional Malay society based on their beliefs and philosophy (Ismail NA and Said I, 2002). Thus, the surrounding of the Malay traditional house also relates to its internal activities. In general, landscape development in traditional Malay society is to achieve harmony with the environment.

The Malay landscape emphasises beauty as part of their culture. The aesthetic demand begins from the front areas of a house, followed to the rear and up to the backyard. Each spaces created represents their own roles and functions to pursuit daily need and activities. Aesthetic is important as the Malay culture are very particular in celebrating their guest. 
Therefore the Malays would design their front areas or compound as beautiful as possible in order to attract guest and neighbours to come to their house. This value is parallel to their culture of welcoming people to their house as it would bring good reward by the Al-Mighty and keep the good relationship with the community or their neighbours.

\subsection{Islamic Garden Concept}

This section discusses the understanding of Islamic garden concept by adopting the explanation of the imagery description from the Quran. The descriptions of gardens begin as early as the expressions of paradise contain in the Holy Quran. The Quranic verse has consistently conveyed the imagery impression of greenery, beauty, canals, overwhelming foods which describing garden (Kamil \& Yunos, 2015). For example, in the following verse illustrates the heaven, earth, plants and beauty; "Allah has created the heavens and the earth, and He sends you down rain from the sky with it We cause to grow well-planted orchards, Full of beauty and delight" (Surah An-Naml: 99).

With regards to this relationship between the garden and 'paradise' from the Quran, this paper focuses on the significant elements of the 'paradise' that have been used to compose a garden which is closely representing the Islamic garden.

\subsection{Paradise garden}

Since the arrival of Islam, as a religion in the 7th century, gardens have been described as a metaphor of Paradise or Al-Janna (The Garden). Every time 'heaven' or 'paradise' is mentioned in the holy book of Quran, there is an explanation of flowing water and fruit bearing trees, signifying their prominence to man. The reward for good deeds according to the Quran is a place of shaded trees, flowing water, gardens with sweet fruits and fragrant flower (Kamil \& Yunos, 2015). Meanwhile, Nur Hafizah et al. (2014) describes 'heaven' as a symbol of an area that includes a space advantage, where there are plants, floral, fruits and also the animal.

However, no man can see the 'paradise' until the Judgment Day. Allah Almighty has presented a very detailed description of paradise in Quran. Upon reading Quran one can have an imaginary picture of paradise. For example, there are a few verses of Quran relating to the description of paradise: "(Here is) a Parable of the Garden which the righteous are promised: in it is rivers of water incorruptible; rivers of milk of which the taste never changes; rivers of wine, a joy to those who drink; and rivers of honey pure and clear. In it there are for them all kinds of fruits; and Grace from their Lord.." (Surah Muhammad 47:15)

There are so many other verses of Quran in which paradise has been portrayed in a lovely manner. Those who believe in Allah, his messenger and have to lead the life on earth to the will of Allah will be given the right by Allah Almighty to enter paradise as been mentioned in the following verse; "And [accompanying them will be their] companions pure, most beautiful of eye, like unto pearls hidden in their shells. [This will be] a reward for what they did [during life]. No empty talk will they hear there, nor any call to sin, but only the tiding of inner soundness and peace." (Surah AI Waqia 56:22-26). 


\subsection{Principles and landscape elements}

The discussions about 'paradise', Islamic garden and its concept are varies. Many researchers have raised attention on the specific design concept while others begins to relate the concept within a wider context. According to Kamil \& Yunos (2015) study has reviewed the theoretical background of elements engaged in the Islamic Garden such as trees and water and environment such as calmness, beauty and balance. For example, Kamil \& Yunos (2015) analyses the philosophical implications of the garden elements in the Quran being potrayed in a surah; Al-Waqiah. With the aid of the understanding in 'Tafsir of the Fizilal', those elements and principles of paradise imagery of Surah Al-Waqiah are listed in the table below:

Table 1: The typical Quranic paradise imagenery derived from Surah Al-Waqiah

\begin{tabular}{ccc}
\hline No. & Element / Ambient & Characteristic \\
\hline 1 & Facilities & Impressive, serenity, exciting \\
2 & Comfort and balance & Amazing, Sensational \\
3 & Water, Fruit, Animal, Plantation & Never-ending, lush and greenery \\
4 & People, Society & Stunning, unity \\
5 & Conversation, Discussion & Noble, worthy, educated \\
\hline
\end{tabular}

(Source: Kamil \& Yunos, 2015)

From the Surah Al-Waqiah findings, a paradisiacal garden is described as an unlimited paradise and secures space, with diverse trees planted in specific locations, accessed to through eight gates. Therefore, Kamil \& Yunos (2015) emphasised the findings as the Islamic Garden principles based on applying the ideological principle in Islamic faith and Quranic paradise imagery.

\subsection{Plants in Quran}

Plants in Quran have been conveyed in many ways. According to Eskandari \& Jalali (2013) reviews on plants in Quran, they discussed that the plants were not only used as food but also as ornamental plants (the grain in the blade; and aromatic herbs, Surah Al-Rahman; 12), shaded plants (near them shall be its shade, Surah Al-Insan;14), used as an index of scale for example mustard to predicate accuracy (In Surah Al-Luqman; 16 said: 'My son, if it should be but the weight of one grain of mustard seed, and though it be on a rock, or in the heavens, or in the earth, Allah shall bring it. surely, Allah is the subtle, (Surah Al-Luqman; 16) or as punishment for guilty humans named as "Zaqqum" grows from the bottom of hell (Surah As- Safat; 64) (Eskandari \& Jalali, 2013).

\subsection{Features and characteristics of design from the Quran}

The 'aesthetics', according to the Quran, are the beauty presented by the character of Allah (God). The aesthetic was also mentioned to be the natural beauty of the heavens and the earth. For example, the Quran refers beauty specifically for sky lighting. This shows that decorate the light can also be important in human and is one of the beautification.

In other 'beautiful' verses of the Qur'an, the creation of man has been attributed. Colour, consistency and proportions of such features have been referred to Quran. Also, Quran also 
refers to a beautiful woman and her beauty to keep these commands. God created man and a special creation. Also, a new man is inherent to this industry. In fact, all the attributes of God in the creation of man and thus all these attributes used in humans are reflected. Then, all these characters are reflecting for a human.

Plants and water are a factor in the vitality and beauty of the characteristics of man-made beauty. The beauty of the architecture can be given to the needs and size of the human and a combination of nature and architecture, means the combination of natural beauty and manmade beauty (art) that is not in conflict with each other. Architecture, based on this elementary composition and characteristics mentioned in the definition is unique. Therefore, the development of eternal meaning and truth and beauty in art and architecture begins for the audience.

\subsection{Interpreting the Malay Landscape through Islamic Concept}

Based on the previous discussions on the Malay landscape and Islamic garden, this paper further reviews on how these generic concepts correlate between one another. The similarities together with the differences bet both concepts are resulted by assimilation process in Malay society after Islam presence has to lead to a huge impact on daily life till Malay and Islam could not be a separated.

Moreover, Nur Hafizah et. al (2014) has also begun to convey the Malay landscape concept and elements through the image of Islamic garden which is depicted from the image of paradise garden. In addition, he added that paradise or heaven was used to symbolise as an area that includes a space advantage, where there are plants, floral, fruits and also an animal. As seen in plant organisation in Malay society' house area, there are several same speculations as gardens that are visualised in heaven as all of it have a certain function that is beneficial for their daily life. For example, the functions and advantages of plants in Malays landscape that are significant with Islamic concept were interpreted through the followings surah from the Quran.

\subsection{Plant cultivate in Malay landscape involved fruit trees, herbs or medicines for kitchen basics}

There have been many verses explaining the functions of plants as resources for food, medicine and survival. The Quran has repeatedly used the words corps, livestock, fruits and food as been mentioned in Surah Ali-Imran (3:14) and Surah Al An'am 6: 99) :"It is He Who sends down water (rain) from the sky, and with it We bring forth vegetation of all kinds, and out of it We bring forth green stalks, from which We bring forth thick clustered grain. And out of the date palm and its spate come forth clusters of dates hanging low and near, and gardens of grapes, olives and pomegranates Look at their fruits when they begin to bear, and the ripeness thereof. Verily! In these things there are signs for people who believe." (Surah AlAn'am: 99).

\subsection{Beauty or aesthetic value in design}

Some of the society thought that Islam did not care about the beauty for there is no basis in 
Quran and also as-sunnah about it. The truth is the Islam itself already too beautiful because Allah is too beautiful and He loves beauty and it is said in hadith that a human duty on earth, one of them is to beautify the earth (Fatos, 2011). "Allah is indeed beautiful and He loves the beauty." (Hadith Muslim). Allah s.w.t's mighty can be seen through His creations' beauty so that every creature bow to this one and only creator. It is, however, stated in Surah An-Naml as below:

It is understandable that the beauty not only beautiful and delicious to one's sight, but it also contains hidden meanings. Islam's beauty could be seen in the way Muslims celebrates guests to their home, and in a landscape context, Malay society usually cultivates beautiful and bright colour flowers around their home to bring out 'sense of welcoming' (Abdullah Sani, A., in Nur Hafizah et al, 2014).

Besides that, Quran also described that: "And you see the earth barren, but when We send down water (rain) on it, it is stirred (to life), it swells and puts forth every lovely kind (of growth)." (Surah Al-Hajj 22: 5). This verse also had clearly stated that plants and crops are significant elements in the existing beauty of this earth. Thus, we can see here how the connection of the flora was utilised to produce the image of beauty not only in heaven but also on earth. So does flowers that produce good fragrant are mostly plant in Malay landscape also symbolise Islamic elements (Abdullah Sani, A., in Nur Hafizah et. al, 2014).

Together with beauty, Fatos (2011) has related it with fragrant. There is a saying that roses fragrant are Prophet Muhammad s.a.w's odour and the symbol of beauty (Fatos, 2011). Besides, Nur Hafizah et al (2014) has discussed the implementation of fragrant and flowers between the Islamic teachings that encourage the Muslims to wear fresh or fragrant odour with the Malay society's culture who also love to cultivate plant that produce fragrant plant, not only for celebrating the guest but also as perfume for ladies and putting them (flowers) on their hair.

The practice of appreciating fragrant from flowers could be value with paradise visual which is also said to have a pleasant fragrant. This relates with Imam Ibnu Qayyim r.a explain that: "It is true Allah had shown to His followers of this world some effect reflecting paradise's characteristic, for example fragrant and delicious smell, cool, beautiful scenery, good quality fruits, all the heavenly joy and leisure."

\subsection{Plants symbolises good deeds}

In the Malay cultures, there is a practice of giving present or gift to people which symbolise their appreciation and a kind of attending or serving their guest. While in Islam, there are also urgency and encouragement in giving charity or 'sadaqah' to people in which were counted as good deeds. The Malay landscapes prioritise their guest more than themselves. They composed their 'front compound' especially with the aesthetic flowers to create the sense of welcoming and inviting. This will subsequently develop a good relationship with the neighbourhood /community (Nur Huzeima \& Byrd, 2012). As it is quoted in Quran: "O! You who believe! Spend of the good things which you have (legally) earned, and of that which We have produced from the earth for you, ." (Surah Al-Baqarah 2: 267).

Besides flowers and aesthetic plants, fruits and other edible plants are also essential in Malay landscape that will not only valuable as food and resources but also could contribute 
to being an alternative as to exchange or provide present for guest or neighbours.

\subsection{Relating Culture and Beliefs towards Future Resilient}

This paper are aligned with Kamil \& Yunos (2015) and Nur Hafizah et. al (2014) ideas on how the general Islamic garden principles and Quranic paradise imagery derived from verse of Quran can help people to establish systems, regulations, attitudes and views in order to understand and control their worldly life in accordance with their needs, region and time. The ideas of implementing the Islamic garden into the garden in Malaysia is perceived as relevant and encourage the effort to support the governance approach in creating an Islamic environment (Kamil \& Yunos, 2015). This paper also interpreted the significant connections between the implementations of Malay landscape functions and elements with the Islamic garden that a by the related verses of the Holy Quran.

Therefore, this paper foresees a potential mutual adaptation between man and nature through the reflection from the Quran will be a good platform for establishing the MalayTraditional landscape together with the Islamic garden concept towards future considerations. The concern is to establish the value of the landscape not only for human survival but also towards the ecological resilient in the environment.

\section{Acknowledgement}

This paper is part of the extension in demonstrating the understanding of cultural landscape; in particular between the Malay Landscape and the Islamic Garden Concept.

\section{References}

Adnan, N., \& Othman, N. (2012). The relationship between plants and the Malay culture. Procedia-Social and Behavioral Sciences, 42, 231-241.

Pourjafar, M. R., \& Vasigh, B. (2008). Study of various Landscape Elements in Quran with respect to Soreh-e AIRahman. Bagh-I-Nazar Spring-Summer 2008, Volume 5, Number 9; Page(s) 23-34.

Ani, A., Mohamed, N., \& Rahman, N. A. (2012). Socio-Cultural Influences in The Composition of Traditional Malay House Compounds in Rural Melaka. ALAM CIPTA, International Journal of Sustainable Tropical Design Research and Practice, 5(1).

Bemanian, M. R., Ansari, M., Noqrehkar, A., \& Vasiq, B. (2011). Elements of Landscape Architecture In The Holy Quran. Soffeh Summer 2011, Volume 21, Number 53; Page(s) 514.

Fatos, A., 2011. Islamic gardens with a special emphasis on the Ottoman paradise gardens: 
The sense of place between imagery and reality. Online Journal of Communication and Media Technologies, 1(4): 55-96

Jelani, H., 2004. Bustan Al-Salatin , 'The Garden of Kings': A universal history and adab work from seventeenth-century Aceh. Indonesia and the Malay World, 32(92): 21-52

Kamil, S. M., \& Yunos, M. Y. M. (2015). Establishing Malaysia Islamic Garden Based On Quranic Paradise Imagery: Descriptive Analysis From Tafsir Surah Waqiah. Advances in Environmental Biology, 9(23), 115-119.

Hussain, N. H. M., \& Ahmad, S. (2012). Landscape Design for Malay Contemporary House at Desa Wawasan. Procedia-Social and Behavioral Sciences, 42, 182-189.

Hussain, N. H. M., \& Byrd, H. (2012). Towards a compatible landscape in Malaysia: An idea, challenge and imperatives. Procedia-Social and Behavioral Sciences, 35, 275-283.

Ismail, N. A., \& Ariffin, N. F. M. (2015). Longing for culture and nature: The Malay Rural Cultural Landscape 'Desa Tercinta'. Jurnal Teknologi, 75(9).

Mazehan, S. M., Shuib, B. K., \& Hashim, H. (2013). Value of Rural Landscape from Public Perspectives. In Proceedings of the International Conference on Social Science Research, ICSSR (pp. 4-5).

Nur Hafizah R., Ab. Aziz S., Ramle A., Mohd Sukhairi M.R. (2014) Islamic Elements of Plants Selection on Malay Landscape in Kota Bharu City, Kelantan, Malaysia, Australian Journal of Basic and Applied Sciences, ISSN:1991-8178, 8(2) February 2014, Pages: 265271.

Nur Hafizah R., Ab. Aziz S., Ramle A., Olalere F.E., Mohd Sukhairi M.R., Olalere E.(2015) The Basis of Plants Adoption and It's Application in Landscape of Malay Traditional House, International Journal of Architecture and Urban Development Vol.5, No.2, Spring 2015.

Shokrpour, M, \& Fakherian, P. (2015). Evaluation Of Aesthetics In Architecture From The Perspective Of Quran. Cumhuriyet Science Journal, 36(4), 1611-1616.

Zakaria, A. Z., Salleh, I. H., \& Rashid, M. S. A. (2013). Landscape Furniture Present in the Ancient Malay Garden According to Old Manuscripts in Malaysia. Procedia-Social and Behavioral Sciences, 91, 28-35. 